\title{
Decadal-scale responses of larval fish assemblages to multiple ecosystem processes in the northern Gulf of Mexico
}

\author{
Barbara A. Muhling ${ }^{1, *}$, John T. Lamkin ${ }^{2}$, William J. Richards ${ }^{2}$ \\ ${ }^{1}$ Cooperative Institute for Marine and Atmospheric Studies, University of Miami, Miami, Florida 33149, USA \\ ${ }^{2}$ NOAA/NMFS/Southeast Fisheries Science Center, Miami, Florida 33149, USA
}

\begin{abstract}
Larval fish assemblages have been systematically sampled across the continental shelf of the northern Gulf of Mexico since the early 1980s. To date, these data have not been analyzed in terms of assemblage structure or variability, despite representing a highly valuable resource for examining decadal-scale change. In this study, multivariate statistical techniques were used to characterize temporal and spatial changes in abundances of the larvae of 20 common fish families from the early 1980s through to the late 2000s. The larvae of some pelagic and mesopelagic families showed marked increases in abundance over the survey time period, while the abundances of some benthic families decreased. Changes in assemblage structure were partially explained by changes in the Gulf of Mexico environment with respect to sea surface temperature and changes in shrimp trawling effort. Outflow from the Mississippi River was also influential on the interannual assemblage variability. However, the strong directional trends apparent in many family groups remained unexplained, and further research is required to discern the drivers of these patterns.
\end{abstract}

KEY WORDS: Gulf of Mexico $\cdot$ Ichthyoplankton $\cdot$ Multivariate statistics $\cdot$ Community analyses

\section{INTRODUCTION}

Marine ecosystems around the world are subject to complex environmental variability, characterized by changes in sea temperature, ocean currents, species composition and food web structure (Francis \& Hare 1994, Anderson \& Piatt 1999, Beaugrand 2004). As a result, marine populations frequently fluctuate in size through time, as conditions for larval survival and recruitment vary, and adults respond to changes in habitat suitability (Smith \& Moser 2003).

Complicating these signals are additional pressures from extractive fisheries. As economically valuable species are preferentially removed, previous interactions with predator, prey and competitor species are altered, leading to cascading effects throughout food webs (Essington et al. 2002, Hinke et al. 2004). In addition, directional processes, such as anthropogenic climate change, affect species assemblages and interactions, as species tolerant of warmer waters slowly displace those with cooler preferences (Nye et al. 2009, Fodrie et al. 2010).

These mechanisms are frequently species-specific and involve many interactions and feedback responses, resulting in complex, non-linear trends of species assemblages through time (Levin et al. 2006). As a result, although abundance indices of commercially important species or trends in easily sampled environmental variables provide some information on ecosystem state, it has been historically difficult to formulate useful and encompassing ecosystem indicators (Hilty \& Merenlender 2000).

Most marine fishes, regardless of eventual adult habitat, have a pelagic larval phase. Multi-year time series of larval fish abundances may track temporal changes in adult biomass across a wide variety of fish 
functional groups, including exploited and unexploited species from a wide range of adult habitats (Smith \& Moser 2003). Larval fish assemblages thus have great potential for use as response indicators to changes in environmental conditions and changes in fishing pressure.

In this study, spatial and temporal trends in larval fish assemblages sampled on the northern Gulf of Mexico continental shelf were examined for evidence of decadal-scale shifts. The Gulf of Mexico is a large, semi-enclosed basin, which is connected to the Caribbean Sea in the south and the Atlantic Ocean to the east via the Loop Current. It supports many commercial and recreational fisheries, most notably shrimp trawling on the continental shelf and pelagic longlining for tuna and swordfish further offshore (Alverson et al. 1996). The continental shelf environment is dominated by seasonal changes in water temperature, as a result of surface heating, and seasonal discharge of low salinity water from rivers onto the northern and eastern shelf (Müller-Karger et al. 1991). Nutrients from this inflow have contributed to the formation of a large hypoxic zone on the Texas-Louisiana shelf, which has expanded in size since the 1980s (Rabalais et al. 2002). In addition, recent studies of inshore species and communities have suggested decadal-scale shifts as a result of warming water temperatures (Cuevas et al. 2004, Fodrie et al. 2010). However, spatial and temporal changes in the broader fish communities of the northern Gulf of Mexico remain largely unknown.

The objective of this study was to characterize spatial and temporal changes in larval fish assemblages on the northern Gulf of Mexico continental shelf from the early 1980s through the late 2000s. We aimed to relate trends in assemblages to environmental metrics and to formulate multivariate ecosystem indicators from larval fish data. It was hypothesized that larvae of fish families occupying similar habitats as adults would show similar decadal-scale changes across the time series and that larvae of benthic families would decrease through time, in response to declining habitat quality caused by bottom hypoxia.

\section{METHODS}

\section{Data collection}

Plankton samples have been collected across the northern Gulf of Mexico under the Southeast Area Monitoring and Assessment Program (SEAMAP) since 1982 (Lyczkowski-Shultz \& Hanisko 2007; Fig. 1). Sampling effort has largely concentrated on the spring (April to May), early summer (June to July), late summer (August to September) and fall (October to November) time periods (Table 1). The plankton sampling was completed using bongo nets,
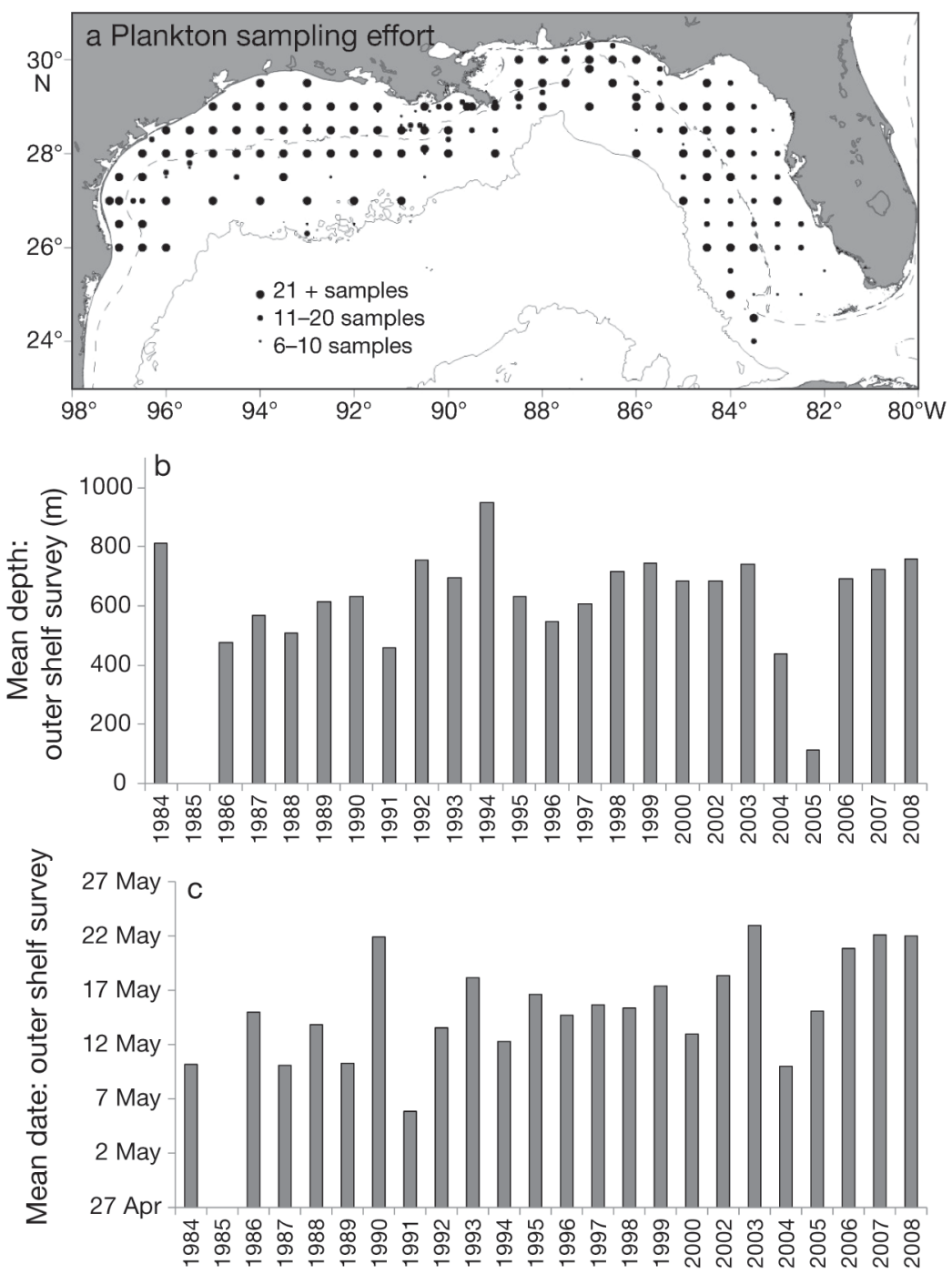

Fig. 1. Sampling effort in the Gulf of Mexico SEAMAP program, 1984 to 2008. (a) Total plankton samples collected, rounded to nearest $0.1^{\circ}$. The solid contour line is $2000 \mathrm{~m}$ depth; the dashed contour is $64 \mathrm{~m}$ depth (boundary of innershelf and outer-shelf zones). (b) Mean sampled depth and (c) mean sampled date of outer-shelf stations occupied during May cruises, to show interannual variability in sampling effort. Samples were collected in all years except 1985 
Table 1. Number of samples collected by year and month through SEAMAP surveys from 1984 to 2008. Five time series with consistent interannual coverage were identified and are shown in gray-ESu ISW: Early Summer Inner Shelf (West); Su IS: Summer Inner Shelf; Fall ISW: Fall Inner Shelf (West); Sp OS: Spring Outer Shelf; Su OS: Summer Outer Shelf. Notes indicate sample subset included in the respective time series

\begin{tabular}{|c|c|c|c|c|c|c|c|c|c|c|c|c|c|c|c|c|c|c|}
\hline & \multicolumn{9}{|c|}{$\begin{array}{l}\text { Inner shelf } \\
\text { (Shallower than } 64 \mathrm{~m} \text { depth) }\end{array}$} & \multicolumn{9}{|c|}{$\begin{array}{l}\text { Outer shelf } \overline{\text { (Deeper than } 64 \mathrm{~m} \text { depth) }}\end{array}$} \\
\hline & Apr & May & Jun & Jul & Aug & Sep & Oct & Nov & Dec & Apr & May & Jun & Jul & Aug & Sep & Oct & Nov & Dec \\
\hline 1984 & 0 & 1 & 37 & 8 & 103 & 0 & 16 & 11 & 0 & 14 & 54 & 9 & 10 & 55 & 0 & 4 & 1 & 17 \\
\hline 1985 & 0 & 0 & 57 & 20 & 6 & 15 & 5 & 0 & 18 & 0 & 0 & 17 & 7 & 19 & 0 & 0 & 0 & 0 \\
\hline 1986 & 0 & 21 & 43 & 6 & 0 & 69 & 29 & 46 & 17 & 10 & 37 & 9 & 3 & 0 & 47 & 7 & 19 & 0 \\
\hline 1987 & 0 & 7 & 19 & 17 & 0 & 80 & 6 & 15 & 0 & 11 & 29 & 6 & 4 & 0 & 42 & 1 & 2 & 0 \\
\hline 1988 & 0 & 5 & 10 & 21 & 13 & 33 & 19 & 31 & 0 & 13 & 30 & 2 & 1 & 12 & 14 & 1 & 5 & 0 \\
\hline 1989 & 0 & 7 & 9 & 24 & 0 & 24 & 36 & 22 & 7 & 1 & 39 & 0 & 3 & 0 & 11 & 17 & 1 & 0 \\
\hline 1990 & 4 & 6 & 13 & 12 & 0 & 34 & 34 & 15 & 4 & 14 & 27 & 27 & 0 & 0 & 15 & 15 & 4 & 0 \\
\hline 1991 & 4 & 0 & 12 & 22 & 12 & 32 & 19 & 16 & 4 & 8 & 20 & 5 & 1 & 9 & 14 & 6 & 2 & 0 \\
\hline 1992 & 0 & 1 & 16 & 22 & 5 & 56 & 15 & 8 & 1 & 9 & 25 & 5 & 4 & 4 & 27 & 8 & 0 & 0 \\
\hline 1993 & 0 & 0 & 14 & 26 & 0 & 39 & 20 & 13 & 2 & 6 & 37 & 16 & 2 & 0 & 24 & 10 & 1 & 0 \\
\hline 1994 & 0 & 1 & 12 & 24 & 0 & 59 & 10 & 1 & 2 & 6 & 62 & 3 & 6 & 0 & 32 & 10 & 0 & 0 \\
\hline 1995 & 1 & 2 & 9 & 0 & 0 & 56 & 0 & 1 & 0 & 18 & 30 & 14 & 0 & 0 & 30 & 0 & 0 & 0 \\
\hline 1996 & 0 & 1 & 8 & 13 & 0 & 64 & 25 & 11 & 12 & 14 & 33 & 4 & 0 & 0 & 39 & 9 & 12 & 39 \\
\hline 1997 & 0 & 2 & 18 & 22 & 0 & 59 & 15 & 10 & 6 & 16 & 31 & 15 & 6 & 0 & 29 & 10 & 9 & 0 \\
\hline 1998 & 0 & 2 & 3 & 5 & 0 & 16 & 16 & 4 & 0 & 2 & 35 & 9 & 0 & 0 & 11 & 2 & 0 & 0 \\
\hline 1999 & 0 & 1 & 11 & 21 & 0 & 80 & 18 & 16 & 3 & 8 & 35 & 5 & 3 & 0 & 48 & 6 & 8 & 0 \\
\hline 2000 & 0 & 0 & 12 & 27 & 0 & 68 & 26 & 17 & 0 & 11 & 30 & 3 & 9 & 0 & 47 & 13 & 7 & 0 \\
\hline 2002 & 0 & 1 & 18 & 20 & 3 & 48 & 25 & 14 & 3 & 14 & 30 & 7 & 7 & 3 & 36 & 12 & 7 & 0 \\
\hline 2003 & 0 & 1 & 12 & 16 & 0 & 81 & 0 & 0 & 6 & 0 & 24 & 6 & 4 & 8 & 46 & 1 & 5 & 0 \\
\hline 2004 & 0 & 0 & 14 & 20 & 0 & 64 & 17 & 14 & 3 & 0 & 4 & 8 & 3 & 0 & 39 & 10 & 9 & 0 \\
\hline 2005 & 0 & 9 & 0 & 1 & 0 & 0 & 35 & 23 & 0 & 3 & 14 & 0 & 0 & 0 & 0 & 31 & 8 & 0 \\
\hline 2006 & 0 & 1 & 15 & 20 & 0 & 79 & 7 & 10 & 4 & 5 & 42 & 7 & 3 & 1 & 46 & 1 & 3 & 0 \\
\hline 2007 & 0 & 2 & 29 & 9 & 5 & 77 & 0 & 0 & 0 & 7 & 28 & 18 & 9 & 7 & 50 & 0 & 0 & 0 \\
\hline 2008 & 0 & 1 & 13 & 21 & 0 & 38 & 0 & 0 & 0 & 11 & 25 & 10 & 3 & 0 & 33 & 0 & 0 & 0 \\
\hline $\begin{array}{l}\text { Sufficient } \\
\text { east/west } \\
\text { coverage? }\end{array}$ & No & No & No & No & No & Yes & No & No & No & No & Yes & No & No & No & Yes & No & No & No \\
\hline Time serie & & & & $\mathrm{Su}$ & & $\mathrm{Su}$ & & & & & $\mathrm{Sp}$ & & & & $\mathrm{Su}$ & & & \\
\hline name & & & IS & W & & IS & & & & & OS & & & & OS & & & \\
\hline Notes & & & $>8 s$ & ${ }^{\circ} \mathrm{W}$ & & & & $9^{\circ} \mathrm{W}$ & & & & & & & $\begin{array}{c}64- \\
400 \mathrm{~m}\end{array}$ & & & \\
\hline
\end{tabular}

(61 diameter, $333 \mu \mathrm{m}$ mesh size) towed in a doubleoblique manner to $200 \mathrm{~m}$ depth, or within 2 to $5 \mathrm{~m}$ of the bottom, as described in Richards et al. (1993) and Scott et al. (1993). Samples from only one bongo net were sorted, and the larvae were identified to the lowest possible taxa at the Sea Fisheries Institute Plankton Sorting and Identification Center, Gdynia and Szczecin, Poland. Catches of larvae were standardized to account for the volume filtered and depth of the sampled water column and were expressed as the number of larvae under $10 \mathrm{~m}^{2}$ of sea surface (Lyczkowski-Shultz \& Hanisko 2007).

Although $>500$ taxa of larval fish were collected, species-level identifications were inconsistent through time. The reasons for this included limitations on larval fish identifications in the taxonomically rich Gulf of Mexico and improvements in the taxonomic descriptions of some families since the surveys commenced in the early 1980s. All of the taxa were therefore aggregated to the family level, and the families with consistent identifications through time (M. Konieczna, Sea Fisheries Institute Plankton Sorting and Identification Center, Poland, pers. comm.) that contributed at least $0.5 \%$ of the total abundance, were selected for analysis (Table 2). These 20 families included $81.4 \%$ of all larvae collected throughout the time series analyzed. Identifications were reliable at the family level from 1984 onwards, with the exception of 2001, giving $24 \mathrm{yr}$ of data in total. Although deeper waters were sampled during some spring surveys, only samples collected in less than $2000 \mathrm{~m}$ of depth were considered in this study.

Environmental data were obtained from both in situ and remotely sensed datasets. An annual index 
Table 2. The 20 larval fish families included in assemblage analyses, including percent contributions to total concentrations (no of ind. $10 \mathrm{~m}^{-2}$ ). Results of family-specific neural network models are also shown, with model $\mathrm{R}^{2}$, along with the relative importance of the 3 explanatory variables

\begin{tabular}{|c|c|c|c|c|c|}
\hline \multirow[t]{2}{*}{ Family } & \multicolumn{5}{|c|}{ Variable importance (out of 100) } \\
\hline & $\begin{array}{c}\% \\
\text { contribution }\end{array}$ & $\begin{array}{c}\text { Model } \\
\mathrm{R}^{2}\end{array}$ & $\begin{array}{c}\text { Water } \\
\text { depth (m) }\end{array}$ & $\begin{array}{l}\text { Year } \\
\text { day }\end{array}$ & Longitude \\
\hline Myctophidae & 14.65 & 0.762 & 100 & 3.4 & 1.6 \\
\hline Bregmacerotidae & 9.98 & 0.541 & 100 & 3.4 & 11.3 \\
\hline Gobiidae & 9.29 & 0.431 & 100 & 27 & 21.2 \\
\hline Engraulidae & 8.31 & 0.462 & 49.4 & 87.1 & 100 \\
\hline Clupeidae & 5.89 & 0.206 & 92.6 & 100 & 56.7 \\
\hline Paralichthyidae & 4.22 & 0.338 & 100 & 36.3 & 1.8 \\
\hline Sciaenidae & 4.06 & 0.529 & 100 & 72.6 & 49.5 \\
\hline Synodontidae & 3.91 & 0.427 & 100 & 11.7 & 3.4 \\
\hline Carangidae & 3.88 & 0.305 & 21 & 100 & 2 \\
\hline Gonostomatidae & 3.73 & 0.695 & 100 & 0.5 & 0.1 \\
\hline Cynoglossidae & 3.08 & 0.375 & 72.8 & 55.2 & 100 \\
\hline Bothidae & 1.69 & 0.21 & 100 & 12.3 & 12.7 \\
\hline Scombridae & 1.68 & 0.338 & 74.9 & 100 & 20.4 \\
\hline Sternoptychidae & 1.68 & 0.481 & 100 & 0.5 & 0.2 \\
\hline Ophidiidae & 1.61 & 0.291 & 100 & 6.9 & 3 \\
\hline Phosichthyidae & 0.90 & 0.501 & 100 & 4.6 & 0.5 \\
\hline Labridae & 0.88 & 0.3325 & 33.3 & 38.9 & 100 \\
\hline Paralepididae & 0.67 & 0.423 & 100 & 3.9 & 3.7 \\
\hline Ophichthidae & 0.66 & 0.22 & 100 & 57.2 & 54.8 \\
\hline Scorpaenidae & 0.59 & 0.324 & 97.5 & 59.4 & 100 \\
\hline
\end{tabular}

blages and to highlight families with particularly strong trends (Fig. 2).

However, an important initial problem was the temporal and spatial variability of sampling effort among years (Fig. 1). Larval fish assemblages may be expected to show strong seasonal and depth-related structure (Grothues \& Cowen 1999), and interannual inconsistencies in sampling thus have the potential to strongly confound underlying trends. Attempts to address this by grouping samples into discrete categories in time or space are often only partially satisfactory, so we instead modeled the influence of water depth, day of the year and longitude on the abundances of each family using multilayer perceptron neural network models (Table 2), built in DTREG software (Sherrod 2003). These models were well suited to our purpose because they can work effectively with the non-normal distributions typical of larval fish data (Segurado \& Araujo

of water temperature in the northern Gulf of Mexico $\left(25\right.$ to $30^{\circ} \mathrm{N}$ ) was obtained from the HadISST product (British Atmospheric Data Center). A 3 yr moving mean of temperature was also included. Mean monthly Mississippi River outflow was obtained from the US Army Corps of Engineers (www.mvn.usace. army.mil/cgi-bin/watercontrol.pl?01160, accessed 15 May 2011), and the annual spatial extent of the continental shelf hypoxic zone was obtained from N. Rabalias (Louisiana Universities Marine Consortium, LUMCON, pers. comm.). Annual shrimp trawling effort in days per year on the Gulf of Mexico shelf was sourced from NOAA-NMFS (Nance 2004, J. Nance pers. comm.). Lastly, total displaced plankton volumes per sample were obtained where available and standardized to volumes per $10 \mathrm{~m}^{2}$ of seawater sampled.

\section{Data analysis}

Observed vs. predicted larval anomalies

Larval concentrations were $\log _{10}(x+1)$ transformed prior to analysis, to address strong rightskewed distribution. These data were then used to describe decadal-scale changes in larval fish assem-
2004). To calculate the relative importance of each predictor variable, the improvement in classification gained by each split that used the predictor was summed, and the results were standardized to a score out of 100 (Sherrod 2003). The observed larval concentrations were then subtracted from predicted values to give residuals, which were used in all further analyses (Fig. 3). These residuals thus described departures from an expected long-term mean, given the position in the Gulf of Mexico and day of the year. The same procedure was then applied to plankton volume data because these were also strongly influenced by water depth and, to a lesser extent, time of year.

To visualize the typical spatiotemporal distributions of larvae from each family, predicted larval concentrations (no. of ind. $10 \mathrm{~m}^{-2}$ ) were calculated for the fifteenth day of each month (April to December), at 20 water depths between 20 and $2000 \mathrm{~m}$, using the neural network models created for each family. All predicted concentrations were divided by the maximum values within each family, giving a maximum predicted concentration of 1 , to allow comparison of more abundant and less abundant families. These standardized predicted larval concentrations were then kriged in Surfer 9 (Golden Software) using day of the year as the $x$-axis and water depth as the 


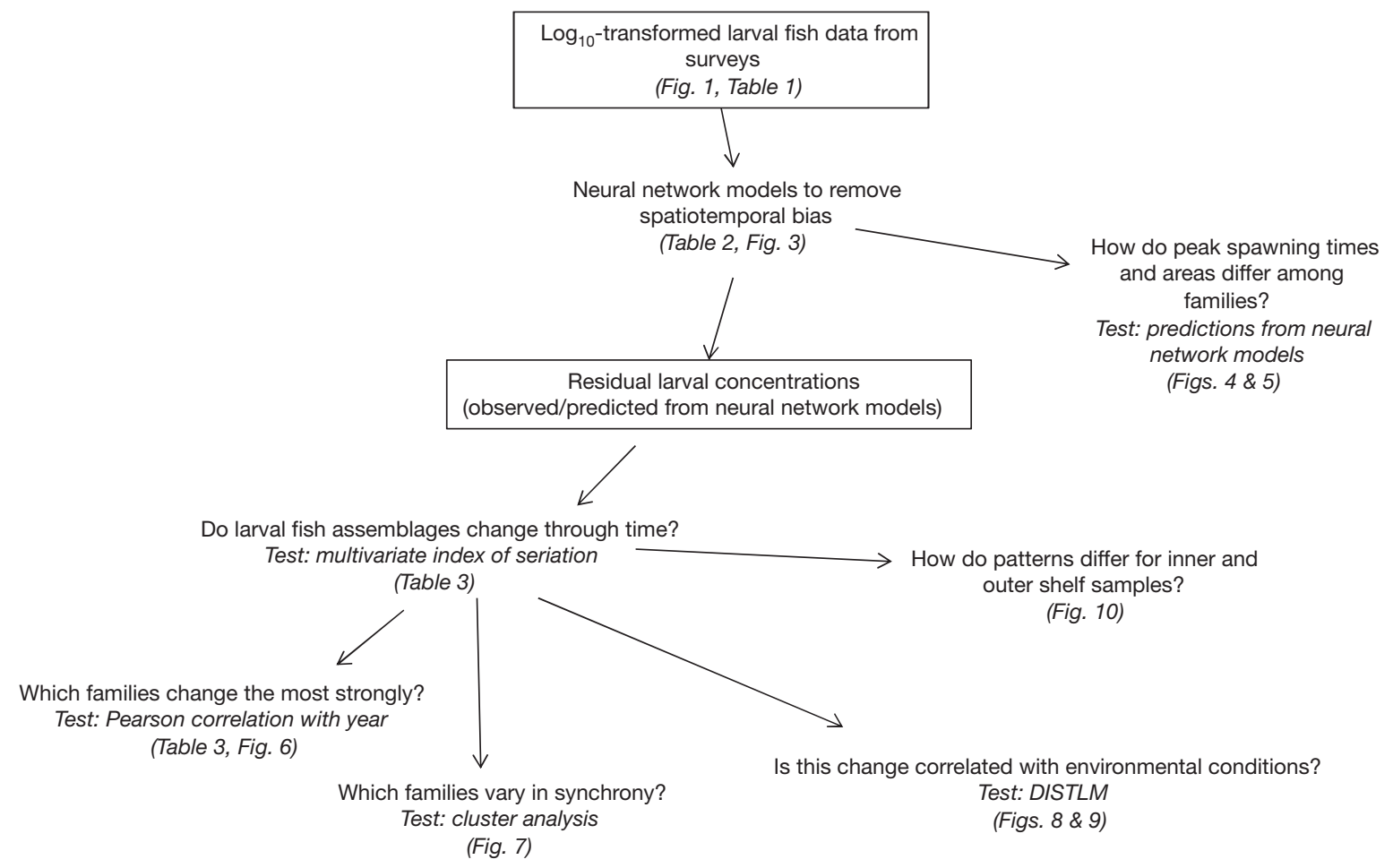

Fig. 2. Data sources (boxes), analyses completed and study objectives

$y$-axis, to allow the comparison of spatiotemporal peaks in larval abundance among families.

\section{Examining change through time}

Because shallow- and deep-water families were likely to have different responses to environmental variability, predicted depth-abundance curves were examined to determine an appropriate depth to separate 'inner shelf' and 'outer shelf' zones. The historical sampling coverage was then examined for each month and depth zone. Months with at least 10 samples collected in at least $20 \mathrm{yr}$ of the survey were selected to use as discreet time series, with years of low coverage $(<10$ samples $)$ excluded. Five time series were selected for analysis: Inner Shelf Early Summer (West), Inner Shelf Fall (West), Inner Shelf Summer, Outer Shelf Spring and Outer Shelf Summer (Table 1). A multivariate index of seriation (Clarke et al. 1993), completed in the Primer-6 statistical package (Clarke 1993, Clarke \& Gorley 2006), was then used to test whether larval fish assemblages had changed directionally through time, within each time series.

Pearson correlations between the mean annual residual larval concentrations for each family and year of each time series highlighted the families that showed the strongest increases or decreases in concentration throughout the survey. To visualize these changes, the location of each sample taken was rounded to the nearest $1^{\circ} \times 1^{\circ}$ location, and the mean residual larval concentrations at each grid point for each family in each year were calculated. Pearson correlations between the mean residual larval concentrations and year at each grid point were then kriged in Surfer 9 for the families showing the strongest changes through time, to obtain a visual representation of the spatial patterns of change. Samples from throughout the year were used, and whole-degree locations with $\geq 5$ samples across $\geq 10$ yr were included.

To find families that tended to vary in synchrony, through space and time, Pearson correlation coefficients among mean family residual concentrations were calculated for each year of each time series, and the associations were displayed using cluster analyses.

Larval assemblages and environmental change

To investigate interannual changes in the Gulf of Mexico environment, Pearson correlations between 


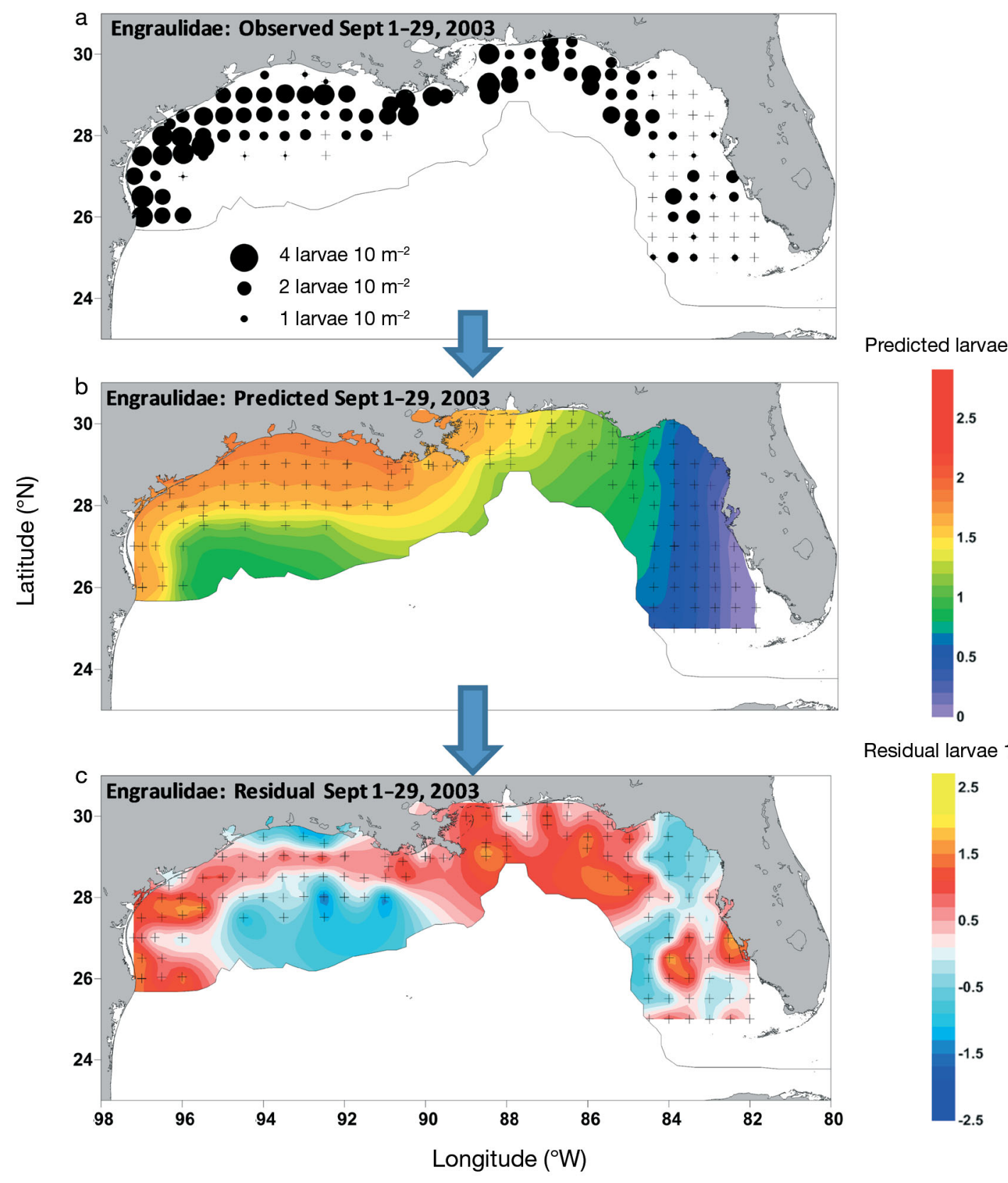

Fig. 3. Sample results of neural network models for Engraulidae larvae collected during September 2003. Sampled stations are shown. (a) Observed Engraulidae larvae collected in September 2003. (b) Kriged predicted abundance of Engraulidae larvae (no. of ind. $10 \mathrm{~m}^{-2}$ ) in September 2003, based on a neural network model. (c) Kriged residual (observed minus predicted) larvae collected

the mean annual environmental variables and year were calculated, and the significance at $\mathrm{p}<0.05$ was assessed after correction for multiple tests. Multivariate patterns were examined using principal coordinates analysis (PCO) on Euclidean distance resemblances. To assess which environmental variables showed the closest correlation to patterns of change in larval fish assemblages, distance-based linear models were constructed in Primer, using the DISTLM routine (Anderson 2001). Variables describing the mean day of the year and water depth of sampling were also included. Because yearday is circular, this variable was transformed using a sine function $\{-\sin [($ yearday +20$) / 52]\}$. This function was fitted in an iterative manner to obtain a mid-August maximum, the time of maximum sea surface temper- 
ature on the Gulf of Mexico continental shelf (MüllerKarger et al. 1991). Residual larval concentrations and environmental variables were averaged across time series and years for both inner- and outer-shelf assemblages. All of the environmental variables were detrended with respect to year before analysis, and an additional variable describing a simple linear gradient was also included. Akaike's information criterion was used to determine the model with the best fit, and the results were displayed using distancebased redundancy analysis. Environmental variables were determined for the same season as each time series, and for the season prior, to attempt to capture some of the influence of environmental characteristics on spawning activity.

The mean annual residual abundances for each family in each year were then summarized into multivariate indicators for both inner- and outer-shelf zones and displayed using PCO with Bray-Curtis resemblances. Only years with sufficient sampling coverage in all of the time series were included in this analysis.

\section{RESULTS}

\section{Spawning peaks and changes through time}

In total, 1305142 larvae were included in the initial analyses. Myctophidae was the most abundant family, contributing $14.65 \%$ of larvae, followed by Bregmacerotidae $(9.98 \%)$ and Gobiidae $(9.29 \%)$. Neural network models incorporating water depth, yearday and longitude explained between $21.0 \%$ and $76.2 \%$ of the variability in larval distributions per family (Table 2). Models of mesopelagic families (e.g. Gonostomatidae, Myctophidae and Phosichthyidae) relied strongly on water depth, which generally explained a large proportion of the observed variance (Table 2). Concentrations of clupeid, carangid and scombrid larvae were strongly related to yearday, while larvae of Engraulidae, Cynoglossidae, Labridae and Scorpaenidae were well described by longitude. Of these latter families, Cynoglossidae and Engraulidae were more abundant in the western Gulf of Mexico, while Labridae and Scorpaenidae larvae were generally more abundant in the east (Table 2).

Predicted larval abundance indices with yearday and depth highlighted different spawning peaks for different families (Fig. 4). Gonostomatidae, Myctophidae, Paralepididae, Phosichthyidae and Sternoptychidae larvae were much more abundant in outershelf waters and were found throughout most of the year. Carangidae, Cynoglossidae and Engraulidae larvae were most abundant in shallower waters during summer, while occurrences of Clupeidae and Sciaenidae were largely confined to inner-shelf waters in fall (Fig. 4).

Predicted abundances of the larvae of 2 inner-shelf and 2 outer-shelf families against water depth $\left(\log _{10^{-}}\right.$ transformed) showed a 'breakpoint' at approximately $64 \mathrm{~m}$ depth (1.8 on a log scale) (Fig. 5). The samples collected at locations shallower than $64 \mathrm{~m}$ were thus denoted as 'inner-shelf' samples, and those at deeper than $64 \mathrm{~m}$ denoted as 'outer-shelf' for all future analyses.

Five discrete time series with consistent temporal and spatial sampling coverage were identified from within the complete dataset (Table 1). Within each of these time series, a significant change in larval fish assemblages occurred over time (Table 3). Within the inner-shelf time series, concentrations of Sciaenidae larvae generally increased, while concentrations of Bothidae and Cynoglossidae larvae generally decreased. In outer-shelf waters, Gonostomatidae, Phosichthyidae and Scombridae larvae all increased (Table 3).

Concentrations of Bothidae larvae decreased most markedly in the western Gulf of Mexico, while spatial changes in concentrations of Cynoglossidae larvae were patchier (Fig. 6). Concentrations of Gonostomatidae and Phosichithyidae larvae were greater in deeper waters, while concentrations of Sciaenidae and Scombridae larvae increased across the continental shelf and slope (Fig. 6).

An analysis of variability of larval concentrations over time, within each time series, showed that the families could be broadly classified into one of 4 groups, based on interannual patterns of abundance (Fig. 7). A group of summer-spawning pelagic families (Carangidae, Engraulidae, Labridae and Scombridae) tended to display similar patterns through time, while a group of 6 largely mesopelagic families also showed some synchrony, with respect to both interannual variability and a tendency to increase in abundance between the 1980s and 2000s. The larval concentrations of 8 largely benthic families (with the exception of Bregmacerotidae) also displayed some similarities in interannual variability.

\section{Larval assemblages and environmental change}

Examination of annual metrics of environmental variability showed that some changes had taken place within the study time period (Fig. 8). Trawl effort and inner-shelf plankton volumes significantly 


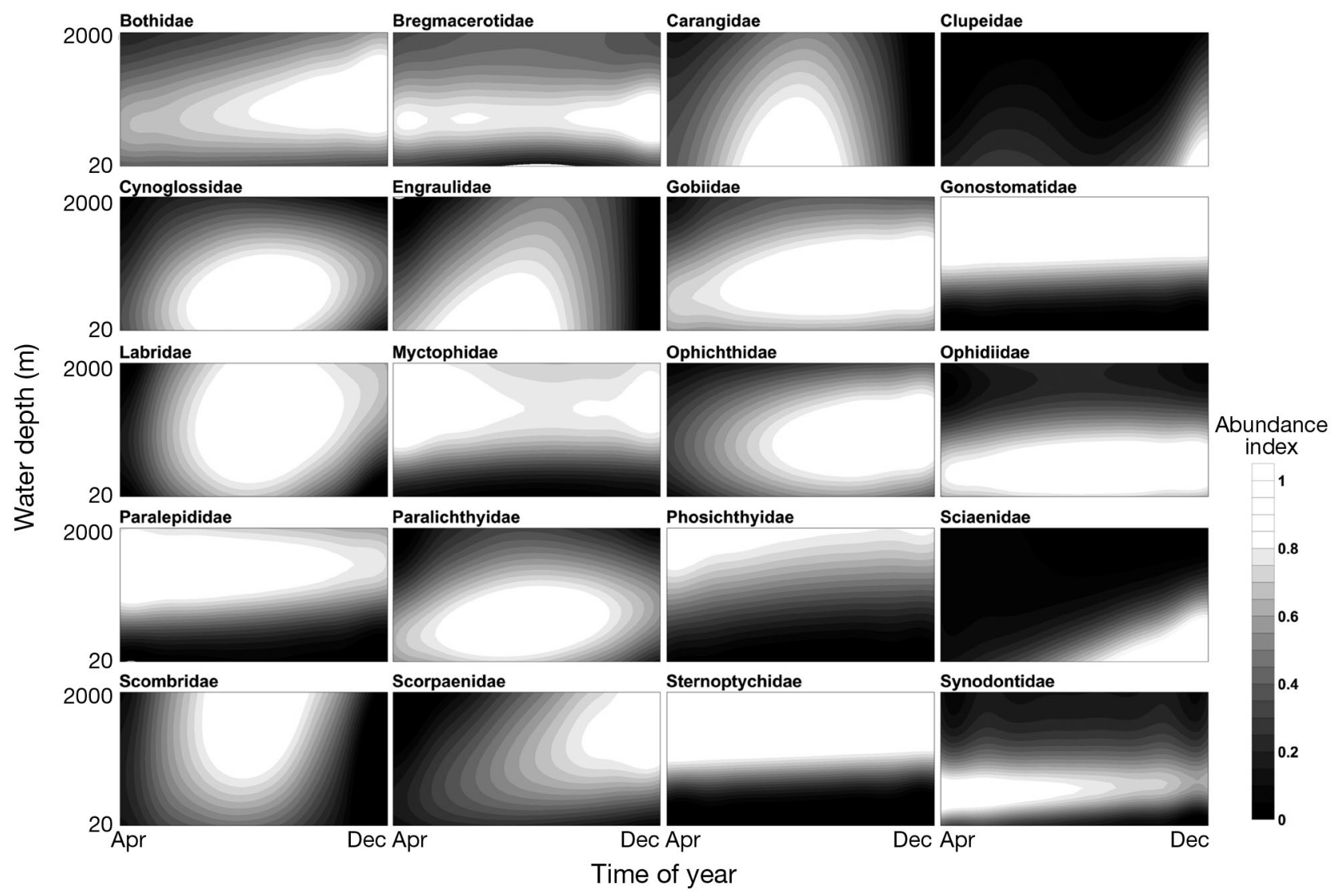

Fig. 4. Predictions of larval abundance from neural network models for 20 fish families. Predicted larval concentrations (no. of ind. $10 \mathrm{~m}^{-2}$ ) were divided by maximum predicted values (abundance index), to allow comparison of more abundant and less abundant families

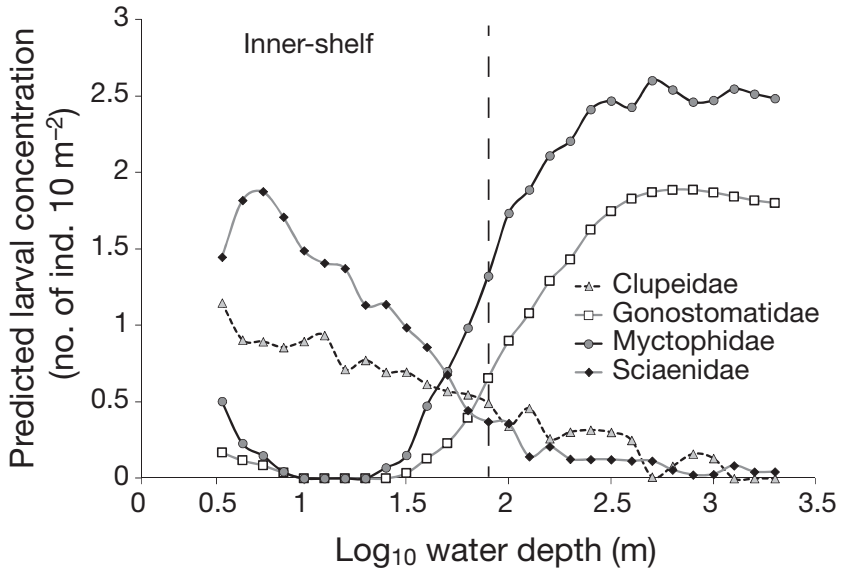

Fig. 5. Mean predicted larval concentrations (no. of ind. $10 \mathrm{~m}^{-2}$ ) of 2 inner-shelf (Clupeidae and Sciaenidae) and 2 outer-shelf (Gonostomatidae and Myctophidae) families against water depth $\left(\log _{10}\right)$. Results are estimated concentrations from family-specific neural network models. The cutoff point for the inner-shelf and outer-shelf zones (64 $\mathrm{m}$ depth, or 1.8 on a log scale) is also shown (dashed line) decreased across the northern Gulf of Mexico, while the $3 \mathrm{yr}$ moving mean of surface temperature increased. The extent of the hypoxic zone increased, and the outer-shelf plankton volumes decreased, but these changes were not significant when a correction for multiple tests was applied. Two PCO ordination axes described $>60 \%$ of the interannual environmental variability, with axis 1 describing the directional increase in surface temperatures and the decrease in trawling effort and plankton volumes and axis 2 describing the interannual variability from Mississippi River outflow and the extent of the hypoxic zone.

Patterns of environmental variability explained modest but significant amounts of variability in the larval fish assemblages (Fig. 9). Inner-shelf assemblages were best correlated with a combination of annual trawling effort $(\mathrm{p}=0.012)$, Mississippi River outflow ( $p=0.06$ ) (both detrended) and a variable describing a simple linear trend $(\mathrm{p}=$ 0.001). Overall, this combination explained $15.7 \%$ 
Table 3. Multivariate index of seriation analysis, for each of 5 time series. $\rho$ statistics and p-values are shown, along with Pearson correlation coefficients (highest only) between mean residual family larval abundances and year

\begin{tabular}{|c|c|c|c|c|}
\hline Time series & $\rho$ & $\mathrm{p}$ & Family & Corr. coeff. \\
\hline $\begin{array}{l}\text { Inner shelf, (west) } \\
\text { early summer }\end{array}$ & 0.248 & 0.007 & $\begin{array}{l}\text { Bothidae } \\
\text { Cynoglossidae } \\
\text { Sciaenidae }\end{array}$ & $\begin{array}{r}-0.748 \\
-0.515 \\
0.489\end{array}$ \\
\hline $\begin{array}{l}\text { Inner shelf, (west) } \\
\text { fall }\end{array}$ & 0.290 & 0.006 & $\begin{array}{c}\text { Clupeidae } \\
\text { Paralichthyidae } \\
\text { Sciaenidae }\end{array}$ & $\begin{array}{l}0.557 \\
0.622 \\
0.642\end{array}$ \\
\hline $\begin{array}{c}\text { Inner shelf, } \\
\text { summer }\end{array}$ & 0.248 & 0.008 & $\begin{array}{c}\text { Bothidae } \\
\text { Cynoglossidae } \\
\text { Sciaenidae }\end{array}$ & $\begin{array}{r}-0.581 \\
-0.587 \\
0.798\end{array}$ \\
\hline $\begin{array}{l}\text { Outer shelf, } \\
\text { spring }\end{array}$ & 0.343 & 0.002 & $\begin{array}{c}\text { Gonostomatidae } \\
\text { Labridae } \\
\text { Scombridae }\end{array}$ & $\begin{array}{l}0.618 \\
0.621 \\
0.664\end{array}$ \\
\hline $\begin{array}{l}\text { Outer shelf, } \\
\text { summer }\end{array}$ & 0.269 & 0.002 & $\begin{array}{c}\text { Gonostomatidae } \\
\text { Phosichthyidae } \\
\text { Scombridae }\end{array}$ & $\begin{array}{l}0.765 \\
0.661 \\
0.753\end{array}$ \\
\hline
\end{tabular}

of the observed variability in larval fish assemblages. Concentrations of Bothidae, Cynoglossidae and Sciaenidae larvae were influential in driving the observed patterns, with Bothidae and Cynoglossidae larvae tending to decrease in abundance between the 1980s and 2000s (as shown by the inverse relationship with the positive linear trend), while Sciaenidae larvae increased (Fig. 9).

Outer-shelf assemblages were best correlated with a combination of a 3 yr moving mean of sea surface temperature $(p=0.001)$, outer-shelf plankton volumes $(p=0.11)$ (both detrended) and a variable describing a simple linear trend $(\mathrm{p}=0.001)$,

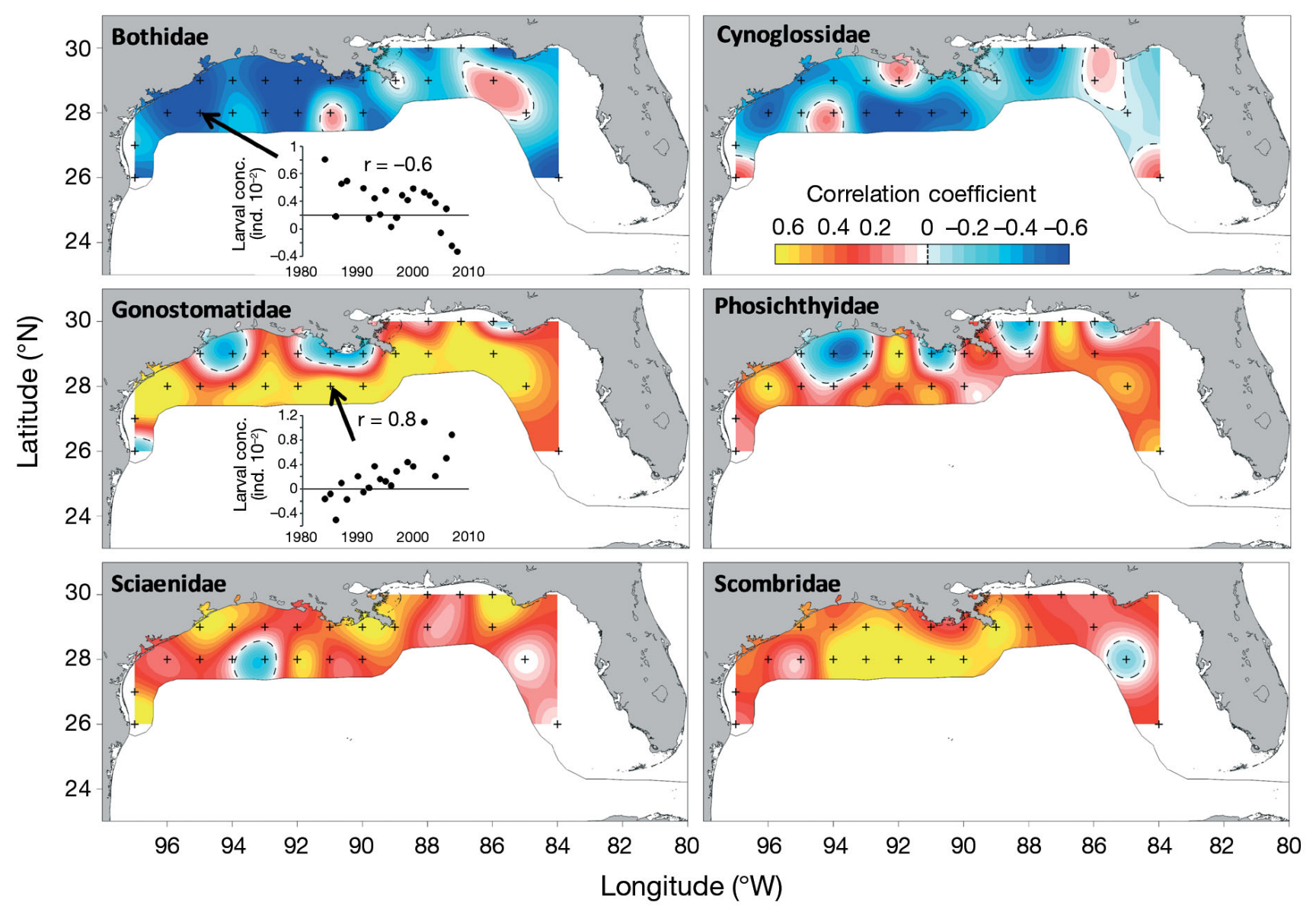

Fig. 6. Pearson correlation coefficients of residual larval abundances (no. of ind. $10 \mathrm{~m}^{-2}$ ) at rounded $1^{\circ} \times 1^{\circ}$ stations, kriged across the northern Gulf of Mexico. Six families highlighted in the multivariate index of seriation analyses are shown. Blue areas indicate a decrease over the course of the survey period (1984 to 2008), while red and yellow areas indicate an increase. Examples of trends in residual concentrations of Bothidae and Gonostomatidae larvae through time at specific grid points are shown 


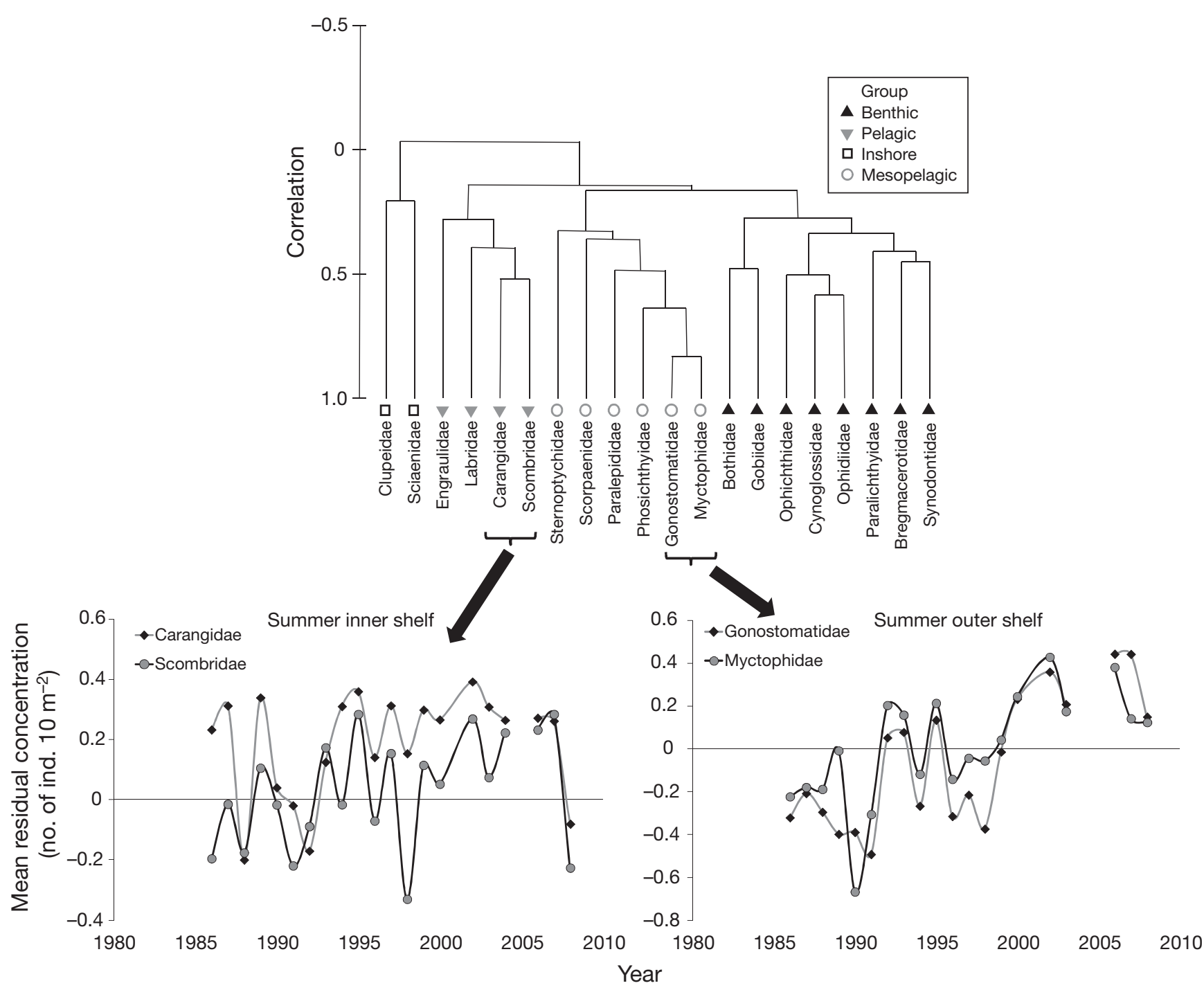

Fig. 7. Cluster analysis of larval fish families computed on a resemblance matrix of Pearson correlation coefficients of residual larval abundances, averaged for time series and year. Examples of covarying families are also shown for 2 inner-shelf and 2 outer-shelf families

which together explained $27.1 \%$ of the observed variability. The concentrations of the mesopelagic families Gonostomatidae, Myctophidae and Phosichthyidae were influential in driving the patterns observed, as were Cynoglossidae and Scombridae larvae (Fig. 9). All of these families were positively correlated with the variable describing a linear trend, suggesting a general increase in abundance through time. Concentrations of both Carangidae and Scombridae larvae were correlated to a moving mean of the sea surface temperature, and all tended to increase between the 1980s and 2000s. In contrast, the increases observed in the concentrations of mesopelagic families were not strongly associated with any of the environmental predictors considered.
To summarize changes in assemblage structure through time for both the inner and outer continental shelf, multivariate indices were developed by averaging the residuals of family abundance for each time series, in each year (Fig. 10). Inner-shelf assemblages showed some changes between samples from the 1980s, 1990s and 2000s; however, outer-shelf assemblages showed a stronger directional change through time (Fig. 10).

\section{DISCUSSION}

Larval fish assemblages in the northern Gulf of Mexico were strongly structured by water depth and 


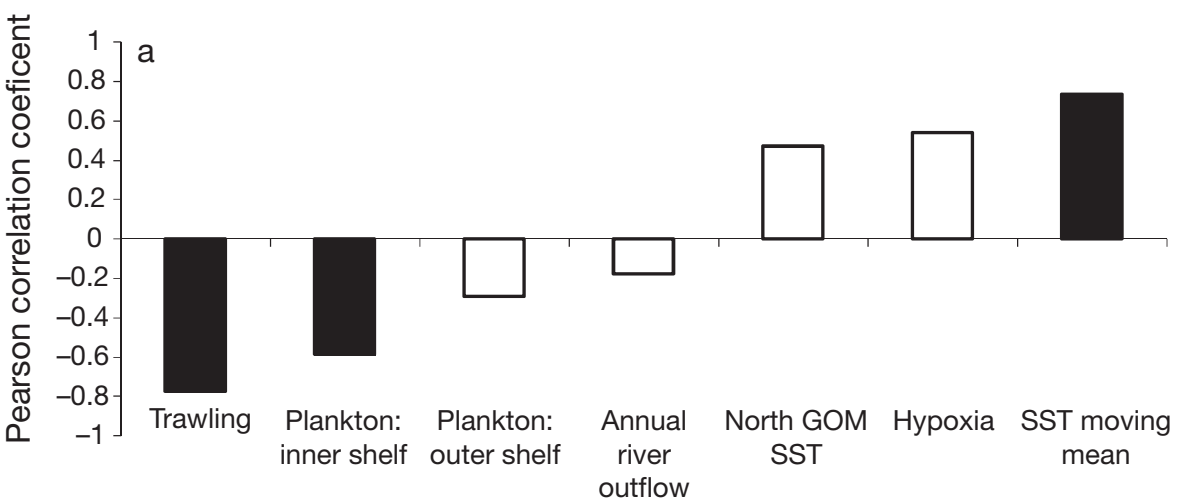

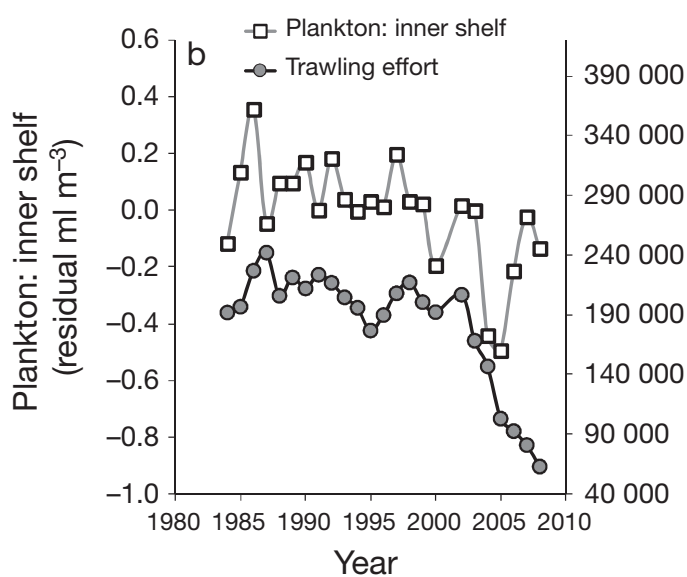

Year

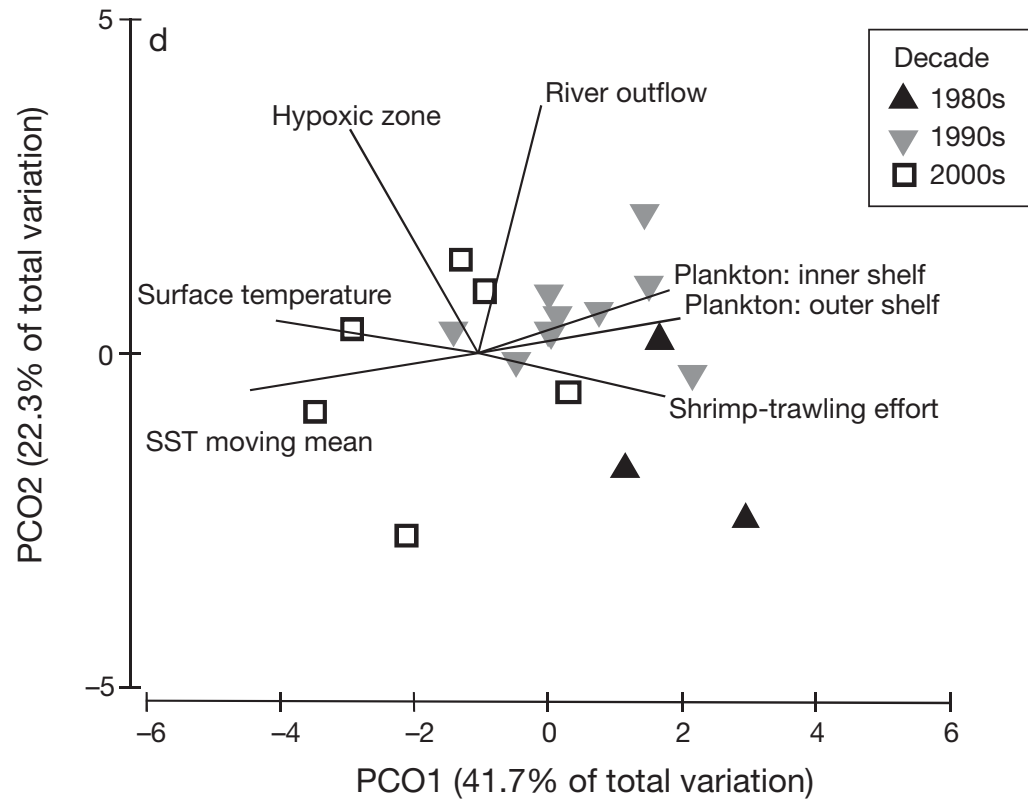

Fig. 8. (a) Pearson correlation coefficients of environmental variables regressed against year. Significant changes $(p<0.05$, corrected for multiple comparisons) are shown with black bars. Trends through time of (b) plankton abundance (ml plankton per $\mathrm{m}^{3}$ seawater sampled) and shrimp trawling effort and (c) the northern Gulf of Mexico (GOM) sea surface temperature (SST, 3 yr moving average) and hypoxic zone size from 1984 to 2008. (d) Principal coordinates (PCO) analysis ordination of mean annual environmental conditions in the northern Gulf of Mexico, 1984 to 2008 season. This pattern is consistent with findings from other regions of the world (e.g. Doyle et al. 1993, Hare et al. 2001, Duffy-Anderson et al. 2006) and usually reflects the depth preferences and spawning seasons of adult fishes. Although migratory movements of adults may complicate matters (e.g. Ophichthidae, which move offshore to spawn) (Ross \& Rohde 2003), and larvae are inevitably mixed and dispersed by ocean currents (Grothues \& Cowen 1999, Muhling et al. 2008), the spatial and temporal characteristics of larval fish assemblages are usually strongly apparent. The oceanography of the northern Gulf of Mexico 
Inner shelf

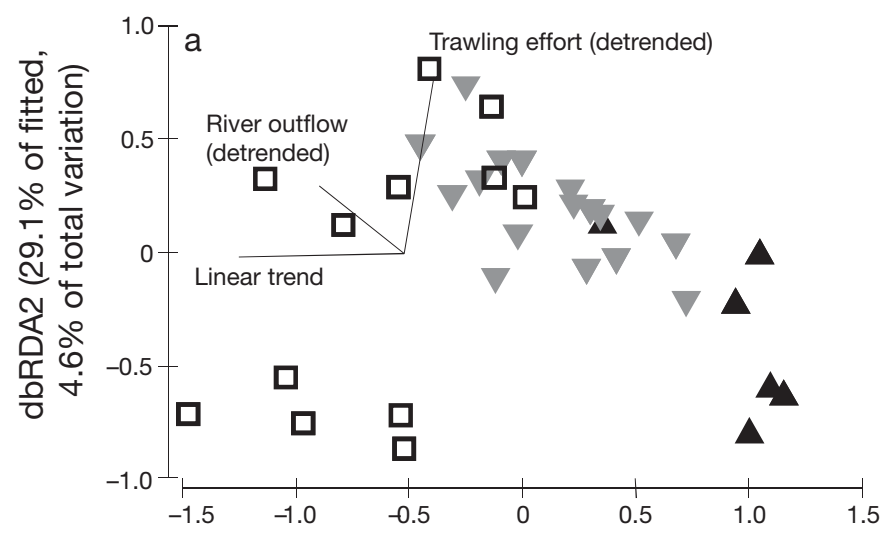

dbRDA1 (57.6\% of fitted, $9.0 \%$ of total variation)

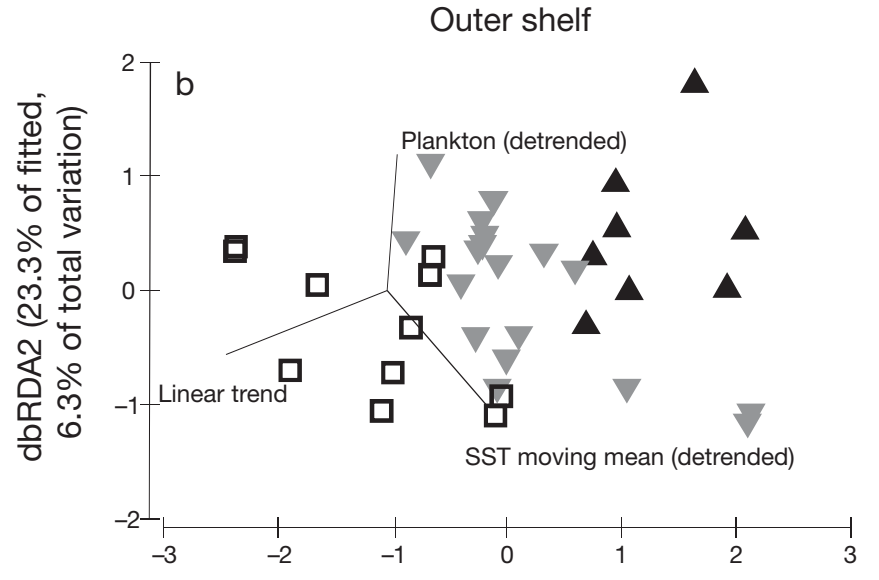

dbRDA1 (63.7\% of fitted, $17.2 \%$ of total variation)

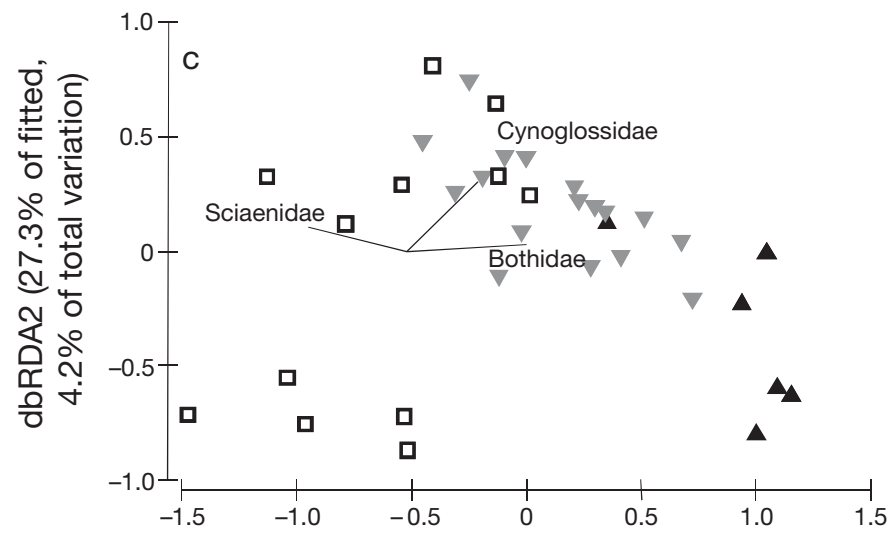

dbRDA1 (60.6\% of fitted, $9.3 \%$ of total variation)

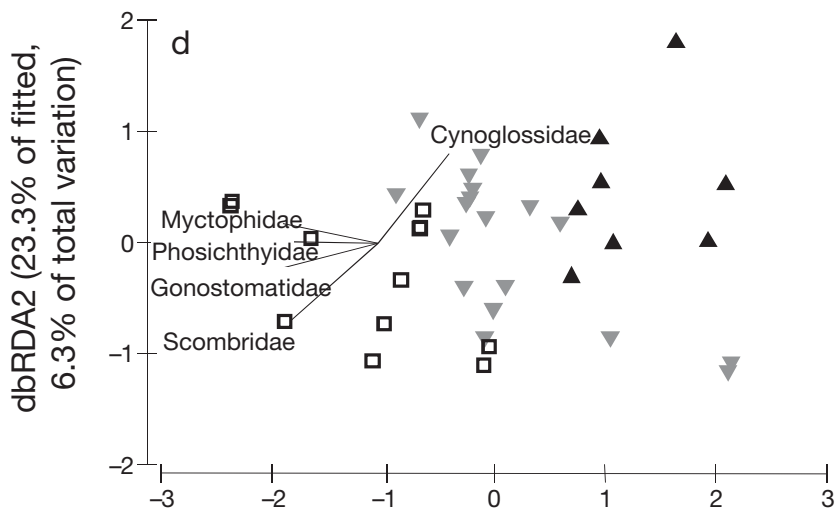

dbRDA1 (63.7\% of fitted, $17.2 \%$ of total variation)

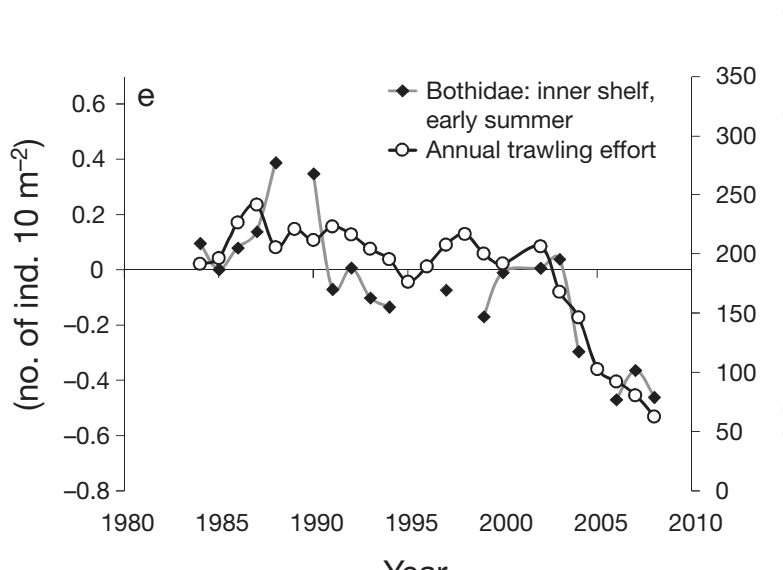

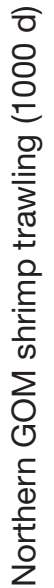

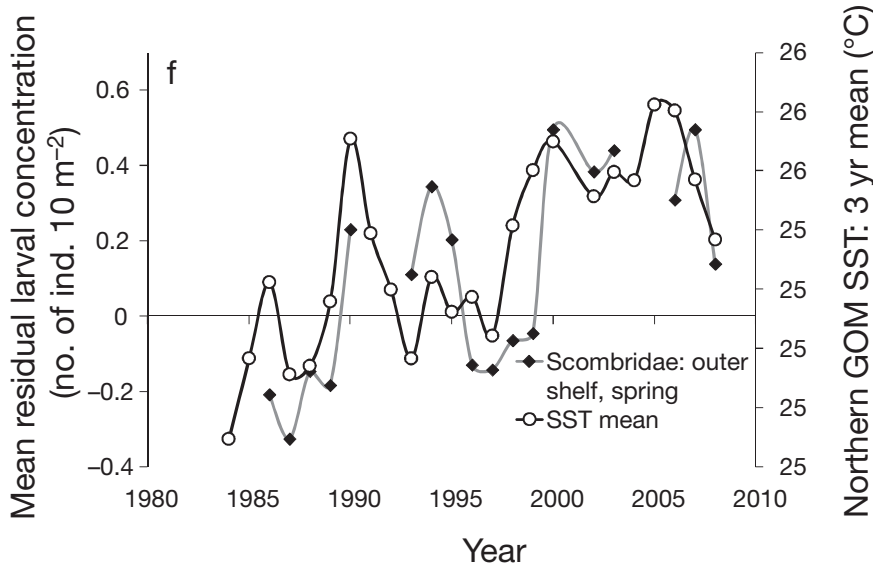

Fig. 9. Results of distance-based linear models of residual larval fish assemblages for $(\mathrm{a}, \mathrm{c}, \mathrm{e})$ inner-shelf and (b,d,f) outer-shelf zones, displayed using distance-based redundancy analysis. Axes describe the percentage of variation described in terms of the selected model and in terms of the total variation of the larval fish assemblage. $(a, b)$ Vectors representing the environmental variables comprising the best selected models (from Akaike's information criterion). (c,d) Vectors representing families with high ( $>0.5$ ) correlation with axes. (e,f) Examples of correlations highlighted by the multivariate analysis, with (e) residual abundances of Bothidae larvae against shrimp trawling effort and (f) residual abundances of Scombridae larvae against a 3 yr running mean of sea surface temperature (SST), for 2 selected time series 

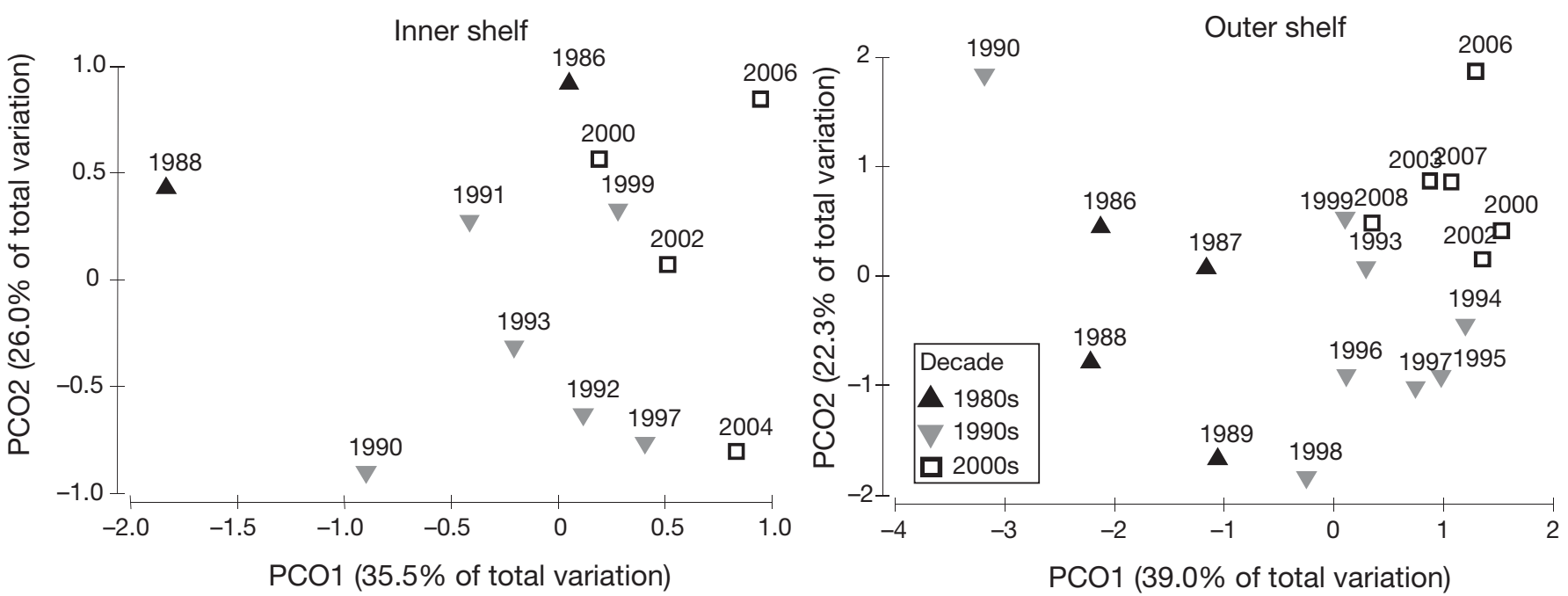

Fig. 10. Multivariate annual indicators derived from residual larval fish abundances in inshore (left) and offshore (right) waters, displayed using principal coordinates (PCOs) analysis

generally favors retention of larvae over the continental shelf, for time scales relevant to typical pelagic larval durations (Ohlmann \& Niiler 2005). This retention is likely to be responsible for the strong crossshelf gradient that structured assemblages.

Once these signals had been largely removed from the dataset, interannual and decadal-scale changes became apparent. Our original hypothesis that larvae of benthic families would decrease was partially supported, but only for some families. In addition, larvae of some other inner-shelf families increased strongly. Also noticeable was the tendency for larvae of mesopelagic families to increase between the start and end of the survey period as well as the decrease in abundance of 2 common inshore families (Bothidae and Cynoglossidae), which partially supported the hypothesis that larvae of fish families occupying similar habitats as adults would show similar decadal-scale changes across the time series.

Although correlations between larval fish assemblages and environmental variables suggested that the drivers behind patterns observed are likely to be complex and are not fully defined in this study, some candidate processes for further examination emerged. The effect of shrimp trawling effort was the strongest and most significant predictor of interannual variability in inner-shelf larval fish assemblages. Trawling effort on the northern Gulf of Mexico shelf has declined since the 1980s, particularly in the 2000s. Trawling was estimated to be a significant source of mortality for sciaenid populations (Diamond et al. 2000), and the decline in trawling effort may have contributed to the observed increase in sci- aenid populations (as estimated using larval abundances). However, this reduction in effort has clearly not had a similarly positive impact on Bothidae and Cynoglossidae populations. Rijnsdorp \& Vingerhoed (2001) showed that trawling in the North Sea may actually improve feeding conditions for some flatfish, which tend to target short-lived, productive benthic organisms. Benthic fish species with different dietary preferences may thus have inverse responses to bottom disturbance from trawling effort, and this may be the case here.

In addition, habitat condition for some adult benthic fishes may have been influential, as the decrease in most benthic families was most pronounced in the region of the summer hypoxic zone (Rabalais et al. 2002). Flatfishes generally avoid hypoxic areas, and their main food sources may also be affected by hypoxic events (Switzer et al. 2009). However, in contrast, Sciaenidae larvae increased in abundance in inshore waters. Because sciaenids are also sensitive to hypoxic events (Craig \& Crowder 2005), it appears more likely from our data that disturbance from shrimp trawling was the dominant driver of change for the benthic fish communities. In addition, outflow from the Mississippi River explained some of the interannual variability in inner-shelf assemblage structure, likely as a consequence of the freshwater plume's influence on primary production (Lohrenz et al. 1997, Dagg \& Breed 2003).

Drivers behind the observed increases in abundances of mesopelagic larvae were more difficult to elucidate. Although increases in abundance of mesopelagic families in concert with environmental 
changes have been recorded previously (Smith \& Moser 2003, Watanabe \& Kawaguchi 2003), interannual variability of tropical North Atlantic and Gulf of Mexico temperatures were not well correlated to observed increases in mesopelagic larvae (Wang \& Enfield 2001). Conley \& Hopkins (2004) suggested that Myctophidae larvae, the most abundant in our collections, were not likely to be prey-limited in the eastern Gulf of Mexico, and although detailed zooplankton assemblage data were not available to us, the total volumes of plankton from SEAMAP samples have actually decreased somewhat since the early 1980s. We therefore did not find evidence of largescale changes in feeding conditions in the Gulf of Mexico, although we did not have the data necessary to evaluate this possibility in any depth.

Mesopelagic fishes are highly abundant in the Gulf of Mexico, as well as in many other world oceans (Sassa et al. 2002, Doyle et al. 1993, Moser \& Smith 1993), and thus represent an important food source for higher predators. They are consumed by other fishes, cephalopods, marine birds and mammals (Cherel et al. 1993, Das et al. 2000, Kitchell et al. 2002, Hinke et al. 2004), with the relative importance of these predators varying by region. It is therefore possible that reduced predation on either larval or adult stages of mesopelagic fishes led to the observed increases. Variability in predation pressures on either larval or adult stages is very difficult to quantify; however, we note that mesopelagic fishes may form a major component of the food webs supporting juvenile and adult tunas and swordfishes in some regions (Menard et al. 2000, Moteki et al. 2001, Hinke et al. 2004). In addition, changes in predator populations may significantly impact abundances of mesopelagic prey species (Essington et al. 2002). Indicators of abundance for these predators in the Gulf of Mexico are difficult to obtain for the length of the larval time series; however, spawning stock biomass estimates for yellowfin tuna Thunnus albacares, bigeye tuna T. obesus and swordfish Xiphias gladius in the western Atlantic Ocean have all declined since the mid-1980s (ICCAT 2009, 2010, 2011). These species all inhabit the Gulf of Mexico, and all have been found to rely heavily on mesopelagic fishes as part of their diets (Moteki et al. 2001), through linkages with cephalopods and smaller scombrid fishes (Hinke et al. 2004). Varying rates of predation on the larvae of mesopelagic species may also be influential but are extremely difficult to assess and are beyond the scope of this study. These connections should be investigated in more depth in future studies, within the context of Gulf of Mexico food webs.
Abundances of the larvae of some smaller pelagic families (Carangidae and Scombridae) also increased through time. While both families are speciose, the majority of carangid larvae were likely to have been Chloroscombrus chrysurus or Decapterus punctatus (Ditty et al. 2004), while the scombrid larvae identified to genus were most commonly Scomberomorus, Auxis, Euthynnus and Thunnus species. Larvae of blackfin (Thunnus atlanticus) and yellowfin (Thunnus albacares) tuna are very difficult to identify visually; however, most Thunnus larvae in the SEAMAP samples were likely blackfin tuna (W. Richards, NOAA-NMFS, pers. comm.). Seasonal abundances of both Carangidae and Scombridae larvae suggested that adults were predominantly summer spawners, with Carangidae larvae more abundant inshore and Scombridae larvae more abundant offshore. Interannual variability in the abundances of both families was correlated to anomalies in sea surface temperature, with warmer years resulting in higher abundances of larvae. This may have been a result of an extended spawning season in warmer years, as water temperatures have been linked to the onset of spawning activity (McPherson 1991, Itano 2000, Muhling et al. 2010) and larval growth rates (Sanchez-Ramirez \& Flores-Coto 1998). It is also possible that reduced predation pressure on smaller, less exploited scombrid fishes (e.g. T. atlanticus, Auxis spp., etc.) by larger, exploited species (e.g. T. albacares and Xiphias gladius) may be significant, as described above. However, given the current lack of detailed information on Gulf of Mexico food webs, these connections must necessarily remain speculative.

As anthropogenic pressures continue to exert influence on the Gulf of Mexico ecosystem, it appears likely that in the short to medium term, temperatures will continue to increase, the size of the hypoxic zone will continue to grow, and trawling activity will remain at historically low levels (Rabalais et al. 2002, Hansen et al. 2006, Caillouet et al. 2008). Results from this study suggest that summer-spawning species, tolerant of hypoxia or able to move away from hypoxic areas, which are not reliant on bottom disturbance, may be favored. However, species-specific studies are needed to examine these issues in more detail because within families, or even genera, responses of species to environmental conditions can be markedly different. As an example, scombrid fishes in the Thunnus genus may include the highly migratory bluefin tuna Thunnus thynnus, which is intolerant of warmer waters and spawns in the Gulf of Mexico 
in spring (Teo et al. 2007), and the more inshoreliving blackfin tuna T. atlanticus, which is a tropical species that spawns in summer. Analyses at the family level, such as the one presented here, thus provide only a starting point for more in-depth, species-level examinations.

The Gulf of Mexico ecosystem is therefore driven by a complex suite of natural and anthropogenic drivers, which impact habitat suitability, predation pressure and entire food webs. Extractive fisheries selectively remove valuable species and impact habitat quality, while nutrient inputs from riverine sources increase productivity and improve feeding conditions for some species, while causing hypoxia, toxic algal blooms and habitat loss for others (Rabalais et al. 2002, Dagg \& Breed 2003, Heil et al. 2007). Climate change may be beginning to result in warming temperatures, with potential for changes in the assemblages of temperature-sensitive species (Cuevas et al. 2004, Fodrie et al. 2010) and the growth and survival of larvae (Wilderbuer et al. 2002). In spring 2010, the Deepwater Horizon oil spill released large amounts of oil into the Gulf of Mexico ecosystem, the biological effects of which are still unclear and may remain so for decades. The need for easily collectable and interpretable indicators is therefore significant and immediate. Larval fish surveys are more easily completed and costeffective than comprehensive surveys of adult fishes across both benthic and pelagic habitats. The larval fish assemblage indicators developed here thus encompass a wide variety of fish functional groups, a valuable property given the range of responses of fish taxa with differing life histories to environmental forcing (Auth et al. 2011), and provide a starting point for future studies of species-specific responses and food web structure.

Acknowledgements. The authors acknowledge the support and assistance of staff at NOAA-NMFS, especially J. Lyczkowski-Shultz, D. Hanisko, G. Zapfe, D. Drass and P. Bond, and K. Williams from the Fish and Wildlife Research Institute, for providing data, helpful information and suggestions. We also thank M. Konieczna and L. Ejsymont from the Sea Fisheries Institute Plankton Sorting and Identification Center, Gdynia and Szczecin, Poland, and the captains and crew of all the NOAA ships who collected data on the SEAMAP cruises. G. Pellegrin and J. Nance provided fisheries and trawl survey data, while N. Rabalais provided data on the extent of the hypoxic zone. Sea surface temperature data were obtained with the assistance of S-K. Lee and Y. Liu from NOAA-AOML, and D. Enfield provided valuable assistance and advice on analyses. We also thank the 5 anonymous reviewers, whose comments improved the manuscript.

\section{LITERATURE CITED}

Alverson DL, Freeberg MH, Murawski SA, Pope JG (1996) A global assessment of fisheries bycatch and discards. FAO Fish Tech Pap 339. FAO, Rome

Anderson MJ (2001) A new method for non-parametric multivariate analysis of variance. Austral Ecol 26:32-46

Anderson PJ, Piatt JF (1999) Community reorganization in the Gulf of Alaska following ocean climate regime shift. Mar Ecol Prog Ser 189:117-123

ICCAT (International Commission for the Conservation of Atlantic Tunas) (2009) Report of the 2008 ICCAT yellowfin and skipjack stock assessments meeting. Collect Vol Sci Pap ICCAT 64:669-927

ICCAT (2010) Report of the 2009 Atlantic swordfish stock assessment session. Collect Vol Sci Pap ICCAT 65: $1-123$

ICCAT (2011) Report of the 2010 ICCAT bigeye tuna stock assessment session. Collect Vol Sci Pap ICCAT 66:1-186

- Auth TD, Brodeur RD, Soulen HL, Ciannelli L, Peterson WT (2011) The response of fish larvae to decadal changes in environmental forcing factors off the Oregon coast. Fish Oceanogr 20:314-328

Beaugrand G (2004) The North Sea regime shift: evidence, causes, mechanisms and consequences. Prog Oceanogr 60:245-262

> Caillouet CW Jr, Hart RA, Nance JM (2008) Growth overfishing in the brown shrimp fishery of Texas, Louisiana, and adjoining Gulf of Mexico EEZ. Fish Res 92:289-302

Cherel Y, Verdon C, Ridoux V (1993) Seasonal importance of oceanic myctophids in king penguin diet at Crozet Islands. Polar Biol 13:355-357

Clarke KR (1993) Non-parametric multivariate analyses of changes in community structure. Aust J Ecol 18:117-143

Clarke KR, Gorley RN (2006) PRIMER v6: User manual/tutorial. PRIMER-E, Plymouth

Clarke KR, Warwick RM, Brown BE (1993) An index showing breakdown of seriation, related to disturbance, in a coral-reef assemblage. Mar Ecol Prog Ser 102:153-160

Conley WJ, Hopkins TL (2004) Feeding ecology of lanternfish (Pisces: Myctophidae) larvae: prey preferences as a reflection of morphology. Bull Mar Sci 75:361-379

> Craig JK, Crowder LB (2005) Hypoxia-induced habitat shifts and energetic consequences in Atlantic croaker and brown shrimp on the Gulf of Mexico shelf. Mar Ecol Prog Ser 294:79-94

Cuevas KJ, Franks JS, Buchanan MV (2004) First record of bone-fish, Albula vulpes, from Mississippi coastal waters. Gulf Caribb Res 17:69-94

> Dagg MJ, Breed GA (2003) Biological effects of Mississippi River nitrogen on the northern Gulf of Mexico-a review and synthesis. J Mar Syst 43:133-152

Das K, Lepoint G, Loizeau V, Debacker V, Dauby P, Bouquegneau JM (2000) Tuna and dolphin associations in the North-east Atlantic: evidence of different ecological niches from stable isotope and heavy metal measurements. Mar Pollut Bull 40:102-109

> Diamond SL, Cowell LG, Crowder LB (2000) Population effects of shrimp trawl bycatch on Atlantic croaker. Can J Fish Aquat Sci 57:2010-2021

> Ditty JG, Shaw RF, Cope JS (2004) Distribution of carangid larvae (Teleostei: Carangidae) and concentrations of zooplankton in the northern Gulf of Mexico, with illustrations of early Hemicaranx amblyrhynchus and Caranx spp. larvae. Mar Biol 145:1001-1014 
Doyle MJ, Morse WW, Kendall AW Jr (1993) A comparison of larval fish assemblages in the temperate zone of the northeast Pacific and northwest Atlantic Oceans. Bull Mar Sci 53:588-644

> Duffy-Anderson JT, Busby MS, Mier KL, Deliyanides CM, Stabeno PJ (2006) Spatial and temporal patterns in summer ichthyoplankton assemblages on the eastern Bering Sea shelf 1996-2000. Fish Oceanogr 15:80-94

Essington TE, Schindler DE, Olson RJ, Kitchell JF, Boggs C, Hilborn R (2002) Alternative fisheries and the predation rate of yellowfin tuna in the eastern Pacific Ocean. Ecol Appl 12:724-734

Fodrie FJ, Heck KL Jr, Powers SP, Graham WM, Robinson KL (2010) Climate-related, decadal-scale assemblage changes in seagrass-associated fishes in the northern Gulf of Mexico. Glob Change Biol 16:48-59

Francis RC, Hare SR (1994) Decadal-scale regime shifts in the large marine ecosystems of the north Pacific: a case for historical science. Fish Oceanogr 3:279-291

> Grothues TM, Cowen RK (1999) Larval fish assemblages and water mass history in a major faunal transition zone. Cont Shelf Res 19:1171-1198

> Hansen J, Sato M, Ruedy R, Lo K, Lea DW, Medina-Elizade M (2006) Global temperature change. Proc Natl Acad Sci USA 103:14288-14293

- Hare JA, Fahay MP, Cowen R (2001) Springtime ichthyoplankton of the slope region off the north-eastern United States of America: larval assemblages, relation to hydrography and implications for larval transport. Fish Oceanogr 10:164-192

Heil CA, Revill M, Glibert PM, Murasko S (2007) Nutrient quality drives differential phytoplankton community composition on the southwest Florida shelf. Limnol Oceanogr 52:1067-1078

Hilty J, Merenlender A (2000) Faunal indicator taxa selection for monitoring ecosystem health. Biol Conserv 92: 185-197

Hinke JT, Kaplan IC, Aydin K, Watters GM, Olson RJ, Kitchell JF (2004) Visualizing the food-web effects of fishing for tunas in the Pacific Ocean. Ecol Soc 9:10, available at www.ecologyandsociety.org/vol9/iss1/art10/

Itano DG (2000) The reproductive biology of yellowfin tuna (Thunnus albacares) in Hawaiian waters and the western tropical Pacific Ocean: project summary. SOEST 00-01 JIMAR Contribution 00-328. Joint Institute for Marine and Atmospheric Research, Honolulu, HI

Kitchell JF, Essington TE, Boggs CH, Schindler DE, Walters CJ (2002) The role of sharks and longline fisheries in a pelagic ecosystem of the central Pacific. Ecosystems 5: 202-216

> Levin PS, Holmes EE, Piner KR, Harvey CJ (2006) Shifts in a Pacific Ocean fish assemblage: the potential influence of exploitation. Conserv Biol 20:1181-1190

Lohrenz SE, Fahnenstiel GL, Redalje DG, Lang GA, Chen X, Dagg MJ (1997) Variations in primary production of northern Gulf of Mexico continental shelf waters linked to nutrient inputs from the Mississippi River. Mar Ecol Prog Ser 155:45-54

Lyczkowski-Shultz J, Hanisko DS (2007) A time series of observations on Red Snapper larvae from SEAMAP surveys, 1982-2003: seasonal occurrence, distribution, abundance and size. In: Patterson WF III, Cowan JH Jr, Fitzhugh GR, Nieland DL (eds) Red snapper ecology and fisheries in the U.S. Gulf of Mexico. Am Fish Soc Symp 60:3-23
McPherson GR (1991) Reproductive biology of yellowfin tuna in the eastern Australian fishing zone, with special reference to the north-western Coral Sea. Mar Freshw Res 42:465-477

Menard F, Stequert B, Rubin A, Herrere M, Marchal E (2000) Food consumption of tuna in the Equatorial Atlantic ocean: FAD-associated versus unassociated schools. Aquat Living Resour 13:233-240

Moser HG, Smith PE (1993) Larval fish assemblages of the California Current region and their horizontal and vertical distributions across a front. Bull Mar Sci 53: 645-691

Moteki M, Arai M, Tsuchiya K, Okamoto H (2001) Composition of piscine prey in the diet of large pelagic fish in the eastern tropical Pacific Ocean. Fish Sci 67:1060-1074

Muhling BA, Beckley LE, Koslow JA, Pearce AF (2008) Larval fish assemblages and water mass structure off the oligotrophic south-western Australian coast. Fish Oceanogr 17:16-31

> Muhling BA, Lamkin JT, Roffer MA (2010) Predicting the occurrence of Atlantic bluefin tuna (Thunnus thynnus) larvae in the northern Gulf of Mexico: building a classification model from archival data. Fish Oceanogr 19: $526-539$

> Müller-Karger FE, Walsh JJ, Evans RH, Meyers MB (1991) On the seasonal phytoplankton concentration and sea surface temperature cycles of the Gulf of Mexico as determined by satellites. J Geophys Res C 96: 12645-12665

Nance J (2004) Estimation of effort in the offshore shrimp trawl fishery of the Gulf of Mexico. Red Snapper SEDAR Data Workshop, April 2004, SEDAR7-DW-24, Charleston, SC

Nye JA, Link JS, Hare JA, Overholtz WJ (2009) Changing spatial distribution of fish stocks in relation to climate and population size on the Northeast United States continental shelf. Mar Ecol Prog Ser 393:111-129

Ohlmann JC, Niiler PP (2005) Circulation over the continental shelf in the northern Gulf of Mexico. Prog Oceanogr 64:45-81

Rabalais NN, Turner RE, Wiseman WJ Jr (2002) Gulf of Mexico hypoxia, A.K.A. 'The Dead Zone. Annu Rev Ecol Syst 33:235-263

Richards WJ, McGowan MF, Leming T, Lamkin JT, Kelley S (1993) Larval fish assemblages at the Loop Current boundary in the Gulf of Mexico. Bull Mar Sci 53:475-537

Rijnsdorp AD, Vingerhoed B (2001) Feeding of plaice Pleuronectes platessa L. and sole Solea solea (L.) in relation to the effects of bottom trawling. J Sea Res 45:219-229

Ross SW, Rohde FC (2003) Collections of ophichthid eels on the surface at night off North Carolina. Bull Mar Sci 72: 241-246

Sanchez-Ramirez M, Flores-Coto C (1998) Growth and mortality of larval Atlantic Bumper Chloroscombrus chrysurus (Pisces: Carangidae) in the southern Gulf of Mexico. Bull Mar Sci 63:295-304

Sassa C, Moser HG, Kawaguchi K (2002) Horizontal and vertical distribution patterns of larval myctophid fishes in the Kuroshio Current region. Fish Oceanogr 11:1-10

Scott GP, Turner SC, Grimes CB, Richards WJ, Brothers EB (1993) Indices of larval bluefin tuna, Thunnus thynnus, abundance in the Gulf of Mexico; modeling variability in growth, mortality, and gear selectivity: ichthyoplankton methods for estimating fish biomass. Bull Mar Sci 53: 912-929 
Segurado P, Araujo MB (2004) An evaluation of methods for modelling species distributions. J Biogeogr 31: 1555-1568

Sherrod PH (2003) DTREG: Classification and regression trees for data mining and modeling. Available at www. dtreg.com/DTREG.pdf

Smith PE, Moser HG (2003) Long-term trends and variability in the larvae of Pacific sardine and associated fish species of the California Current region. Deep-Sea Res II 50: 2519-2536

Switzer TS, Chesney EJ, Baltz DM (2009) Habitat selection by flatfishes in the northern Gulf of Mexico: implications for susceptibility to hypoxia. J Exp Mar Biol Ecol 381: S51-S64

Teo SLH, Boustany A, Dewar H, Stokesbury MJW and oth-

Editorial responsibility: Kenneth Sherman,

Narragansett, Rhode Island, USA ers (2007) Annual migrations, diving behavior, and thermal biology of Atlantic bluefin tuna, Thunnus thynnus, on their Gulf of Mexico breeding grounds. Mar Biol 151: $1-18$

Wang C, Enfield D (2001) The tropical Western hemisphere warm pool. Geophys Res Lett 28:1635-1638

Watanabe H, Kawaguchi K (2003) Decadal change in abundance of surface migratory myctophid fishes in the Kuroshio region from 1957 to 1994. Fish Oceanogr 12: 100-111

Wilderbuer TK, Hollowed AB, Ingraham WJ Jr, Spencer PD, Conners ME, Bond NA, Walters GE (2002) Flatfish recruitment response to decadal climatic variability and ocean conditions in the eastern Bering Sea. Prog Oceanogr 55:235-247

Submitted: July 1, 2011; Accepted: December 2, 2011

Proofs received from author(s): March 19, 2012 